ISSN 1678-3921

Journal homepage: www.embrapa.br/pab

For manuscript submission and journal contents, access: www.scielo.br/pab

\section{An update of new flood- irrigated rice cultivars in the SimulArroz model}

\begin{abstract}
The objective of this work was to model, in the SimulArroz model, the three flood-irrigated rice (Oryza sativa) cultivars currently most grown in the state of Rio Grande do Sul, Brazil. The experiments to calibrate and validate the model were conducted in the municipalities of Cachoeirinha, Santa Maria, Uruguaiana, Santa Vitória do Palmar, and Cachoeira do Sul during four crop seasons. The number of leaves, phenology, aboveground dry matter biomass, and yield of each cultivar were evaluated. The results showed a slight overestimate of the R1, R4, and R9 stages; however, overall, the SimulArroz model had a good performance in simulating rice phenology for the three studied genotypes. Furthermore, the model had a reasonable accuracy in simulating aboveground dry matter and yield. The root-meansquare error (RMSE) for aboveground dry matter (leaves, stems, panicles, and grains) ranged from 0.5 to $3.0 \mathrm{Mg} \mathrm{ha}^{-1}$. For yield, the RMSE ranged from 0.8 to $1.3 \mathrm{Mg} \mathrm{ha}^{-1}$. The calibration of the SimulArroz model is efficient in simulating the growth, development, and grain yield of the most important flood-irrigated rice cultivars in Southern Brazil and can be used to estimate harvest forecast and yield potential, as well for yield gap studies.
\end{abstract}

Index terms: Oryza sativa, mathematical model, yield.

\section{Uma atualização de novas cultivares de arroz irrigado por inundação no modelo SimulArroz}

Resumo - O objetivo deste trabalho foi modelar, no modelo SimulArroz, as três cultivares de arroz (Oryza sativa) irrigado atualmente mais cultivadas no Estado do Rio Grande do Sul. Os experimentos para calibrar e validar o modelo foram conduzidos nos municípios de Cachoeirinha, Santa Maria, Uruguaiana, Santa Vitória do Palmar e Cachoeira do Sul, durante quatro safras. Foram avaliados o número de folhas, a fenologia, a biomassa da matéria seca da parte aérea e a produtividade de cada cultivar. Os resultados mostraram uma leve superestimativa dos estádios R1, R4 e R9; no entanto, no geral, o modelo SimulArroz apresentou bom desempenho na simulação da fenologia do arroz para os três genótipos estudados. Além disso, o modelo teve uma precisão razoável em simular matéria seca da parte aérea e produtividade. A raiz quadrada do erro quadrático médio (RMSE) para matéria seca da parte aérea (folhas, caules, panículas e grãos) variou de 0,5 a 3,0 $\mathrm{Mg} \mathrm{ha}^{-1}$. Para produtividade, a RMSE variou de 0,8 a $1,3 \mathrm{Mg} \mathrm{ha}^{-1}$. A calibração do modelo SimulArroz é eficiente em simular o crescimento, o desenvolvimento e a produtividade de grãos das cultivares de arroz irrigado mais importantes no Sul do Brasil e pode ser utilizada para estimar a previsão de safra e o potencial de produtividade, bem como para estudos de lacunas de produtividade.

Termos para indexação: Oryza sativa, modelo matemático, produtividade. 


\section{Introduction}

Brazil is the largest rice (Oryza sativa L.) producer in the world outside Asia (FAO, 2018; USDA, 2018), with an annual production of approximately 11 tons. The state of Rio Grande do Sul is the largest rice producer in the country, covering 1.1 million hectares and representing $70 \%$ of the national production, with a yield of $7.4 \mathrm{Mg} \mathrm{ha}^{-1}$ (Acompanhamento..., 2018). The analysis of the time series data for rice yield in Rio Grande do Sul, during the first decade of the $21^{\text {st }}$ century, showed a steady increase up to $7.5 \mathrm{Mg} \mathrm{ha}^{-1}$ in 2011, due to the adoption of the Clearfield system by farmers and to genetic breeding, which allowed the development of cultivars resistant to the imidazolinone herbicide, such as IRGA 424 RI, Guri INTA CL, and Puitá INTA-CL (Menezes et al., 2013). Since 2012, rice yields have been stable and these cultivars have been used by around $80 \%$ of the farmers in the last two crop seasons - 2016/2017 and 2017/2018.

In recent years, simulation modelling has been among the most used research techniques in Brazil. Its application in the rice area has focused on: the comparative assessment of different crop models in current and future weather scenarios (Walter et al., 2015; Castro et al., 2018; Ramirez-Villegas et al., 2018), the evaluation of alternative water management strategies (Heinemann et al., 2002), and the study of yield losses caused by weeds (Richter et al., 2019).

In crop modeling, the used parameters are embedded with: genotypic differences regulating phenological development, such as thermal requirements to reach flowering; plant physiological traits, as specific leaf area; and morphological features, including maximum plant height, all which drive the response of processlevel models, leading to yield formation (Hossard et al., 2017). Model parameters can, therefore, be considered as crop "genetic coefficients", providing a mathematical representation of the gene effects under different environmental conditions (Boote et al., 2001). It follows that crop models could be successfully used to analyze the interactions between genotype, environment, and management at the yield level (Rattalino Edreira et al., 2017), by estimating yield potential (Evans, 1993; Ittersum \& Rabbinge, 1997) and quantifying the yield gap between this potential and farm yield (Ittersum et al., 2013).

In Rio Grande do Sul, the SimulArroz model is adopted for studies on irrigated rice modeling (Rosa et al., 2015), since it has already been calibrated for rice cultivars and technological farming. The model is used for a variety of applications at farm and regional levels, aiming to evaluate, for example, on a real-time basis, the impact of current weather on flood-irrigated rice yield potential (Rosa et al., 2015; Ribas et al., 2017). As a result, the SimulArroz model was selected for updating the agricultural zoning for rice in that state; this is the first time a process-based model is being used for agricultural zoning in Brazil (Brasil, 2019). Therefore, this model has a potential use as a tool to improve onfarm management by estimating yield potential and yield gap, according to Grassini et al. (2015).

However, the latest version of the SimulArroz model (Ribas et al., 2017) does not include the IRGA 424 RI, Puitá INTA-CL, and Guri INTA CL cultivars, which are currently the most grown in the state of Rio Grande do Sul. This is crucial for those estimates (Cassman et al., 2003; Lobell et al., 2009; Ittersum et al., 2013), in order to provide information about the yield potential and gap for flood-irrigated rice in Southern Brazil.

The objective of this study was to model, in the SimulArroz model, the three flood-irrigated rice cultivars currently most grown in the state of Rio Grande do Sul, Brazil.

\section{Materials and Methods}

Field experiments were conducted during four crop seasons $(2013 / 2014,2014 / 2015,2015 / 2016$, and 2016/2017) in five sites (Table 1), which represent the range of environments where flood-irrigated rice is grown in the state of Rio Grande do Sul. Two cultivars from the early maturation group (Puitá INTA-CL and Guri INTA CL) and one from the intermediate maturation group (IRGA $424 \mathrm{RI}$ ) were used. These cultivars were chosen because they represent around $80 \%$ of the rice area sown in the state, i.e., approximately 800 thousand hectares (Irga, 2018). Sowing dates were in September, October, November, and December (Table 1), within the period recommended by the rice agroclimatic zoning (Referência). The experimental design were randomized complete blocks with four replicates. Sowing density was $0.1 \mathrm{Mg}$ seed per hectare, at a spacing of $0.17 \mathrm{~m}$ between rows and a seeding depth of $0.03 \mathrm{~m}$. Each plot was $20 \mathrm{~m}$ long and $13 \mathrm{~m}$ wide.

Leaf appearance and phenology were evaluated weekly using the Haun (Haun, 1973) and Counce 
(Counce et al., 2000) scales, respectively. Panicle differentiation (R1 stage) was determined through a destructive sampling of ten plants, and the R1 date was considered when $50 \%$ of the plants were in this development stage. During the crop season in the municipalities of Cachoeirinha and Santa Maria, aboveground biomass was collected by clipping close to the soil, in an area of $1.36 \mathrm{~m}^{2}$ per cultivar, at the following developmental stages: V2 (before irrigation), between $\mathrm{V} 3$ and $\mathrm{R} 1, \mathrm{R} 1$, between $\mathrm{R} 1$ and $\mathrm{R} 4, \mathrm{R} 4$, between R4 and R9, and R9. Aboveground biomass was separated into stems, panicles, and green leaf blades ( $>50 \%$ green area). Subsequently, the samples were oven dried at $60^{\circ} \mathrm{C}$ until constant weight, and then weighed on a precision scale $(0.001 \mathrm{~g})$. To obtain grain yield $\left(\mathrm{Mg} \mathrm{ha}^{-1}\right)$, an area of $20 \mathrm{~m}^{2}$ was harvested for each cultivar.

The genetic parameters calibrated in the SimulArroz model were: maximum rate of the appearance of the first and second leaves; cumulative number of leaves on the main stem; development rates; total thermal time necessary to complete the sowing-emergence phase; total thermal time necessary to complete the emergence-panicle differentiation phase; total thermal time necessary to complete the panicle differentiationanthesis phase; total thermal time necessary to complete the anthesis-maturation phase; radiation use efficiency; aboveground dry matter biomass; assimilate partitioning factors; leaf area index; spike formation factor; and maximum grain weight. The calibration approach was the same as in Rosa et al. (2015) and Ribas et al. (2017).

The evaluation of the model in simulating leaf appearance, phenology, aboveground dry matter (leaves, stems, panicles, and grain yield) was performed with data from the experiments described in Table 1. The SimulArroz model was run in the yield potential mode for the experiments in which dry matter was collected and in the high technology mode for the remaining ones. The potential mode represents experiments without biotic and abiotic stresses, while the high technological mode represents the best farmers in the state, who integrate weed, insect, and disease management with high fertilization (Menezes et al., 2013). The weather data to run the model were obtained from automated weather stations located close to each experimental site, as possible.

The performance of the SimulArroz model was assessed by measuring its accuracy, precision, and trends. For accuracy metrics, the used statistics were: root-mean-square error (RMSE) (Janssen \& Heuberger, 1995), normalized-root-mean-square error (NRMSE) (Janssen \& Heuberger, 1995), bias index (BIAS) (Gabriel et al., 2014), and agreement index (dw) (Gabriel et al., 2014), calculated, respectively, by the equations:

Table 1. Experiments with three flood-irrigated rice (Oryza sativa) cultivars, conducted during four crop seasons (2013/2014, 2014/2015, 2015/2016, and 2016/2017) in five sites in the state of Rio Grande do Sul, Brazil, used to calibrate and evaluate (independent data) the leaf appearance, phenology, dry matter partitioning, and yield submodels in the SimulArroz model.

\begin{tabular}{|c|c|c|c|c|c|}
\hline \multicolumn{2}{|l|}{ Data } & \multicolumn{2}{|c|}{ Calibration } & \multicolumn{2}{|c|}{ Evaluation } \\
\hline $\begin{array}{l}\text { Experiment } \\
\text { (site) }\end{array}$ & $\begin{array}{l}\text { Soil type } \\
\text { (clay \%) }\end{array}$ & $\begin{array}{c}\mathrm{n}^{(1)} \\
\text { (sowing date range) }\end{array}$ & $\begin{array}{l}\mathrm{n} \text { (cultivar maturation } \\
{\text { group })^{(2)}}^{\text {gat }}\end{array}$ & $\begin{array}{c}\mathrm{n} \\
\text { (sowing date range) }\end{array}$ & $\begin{array}{l}\mathrm{n} \text { (cultivar maturation } \\
\text { group) }\end{array}$ \\
\hline $\begin{array}{l}\text { Cachoeirinha } \\
\left(-29^{\circ} 95^{\prime} \mathrm{S},-51^{\circ} 12^{\prime} \mathrm{W} \text {, at } 17 \mathrm{~m}\right)\end{array}$ & $\begin{array}{l}\text { Typic Albaqualf } \\
\qquad(6 \%)\end{array}$ & $\begin{array}{l}2 \text { (Oct. } 01 \text { to } \\
\text { Nov. 09) }\end{array}$ & $\begin{array}{c}3 \text { (early - } \\
\text { intermediate cycle) }\end{array}$ & $\begin{array}{l}33 \text { (Oct. } 18 \text { to } \\
\text { Dec. } 15 \text { ) }\end{array}$ & $\begin{array}{c}3 \text { (early - intermediate } \\
\text { cycle) }\end{array}$ \\
\hline $\begin{array}{l}\text { Cachoeira do Sul } \\
\left(-30^{\circ} 02^{\prime} \mathrm{S},-52^{\circ} 53^{\prime} \mathrm{W} \text {, at } 68 \mathrm{~m}\right)\end{array}$ & $\begin{array}{l}\text { Typic Albaqualf } \\
\qquad(6 \%)\end{array}$ & - & - & $\begin{array}{l}20 \text { (Sept. } 01 \text { to } \\
\text { Dec.15) }\end{array}$ & $\begin{array}{c}3 \text { (early - intermediate } \\
\text { cycle) }\end{array}$ \\
\hline $\begin{array}{l}\text { Santa Vitória do Palmar } \\
\left(-33^{\circ} 51^{\prime} \mathrm{S},-53^{\circ} 35^{\prime} \mathrm{W} \text {, at } 24 \mathrm{~m}\right)\end{array}$ & $\begin{array}{l}\text { Typic Albaqualf } \\
\qquad(6 \%)\end{array}$ & - & - & $\begin{array}{l}16 \text { (Sept. } 01 \text { to } \\
\text { Dec. } 15 \text { ) }\end{array}$ & $\begin{array}{c}3 \text { (early - intermediate } \\
\text { cycle) }\end{array}$ \\
\hline $\begin{array}{l}\text { Santa Maria } \\
\left(-29^{\circ} 72^{\prime} \mathrm{S},-53^{\circ} 71^{\prime} \mathrm{W} \text {, at } 95 \mathrm{~m}\right)\end{array}$ & $\begin{array}{l}\text { Typic Hapludalf } \\
(43 \%)\end{array}$ & - & - & $\begin{array}{l}15 \text { (Oct. } 24 \text { to } \\
\text { Dec. } 03 \text { ) }\end{array}$ & $\begin{array}{c}3 \text { (early - intermediate } \\
\text { cycle) }\end{array}$ \\
\hline $\begin{array}{l}\text { Uruguaiana } \\
\left(-29^{\circ} 83^{\prime} \mathrm{S},-57^{\circ} 08^{\prime} \mathrm{W} \text {, at } 74 \mathrm{~m}\right)\end{array}$ & $\begin{array}{l}\text { Lithic Udorthent } \\
\qquad(39 \%)\end{array}$ & - & - & $\begin{array}{l}23 \text { (Sept. } 01 \text { to } \\
\text { Dec. } 15 \text { ) }\end{array}$ & $\begin{array}{c}3 \text { (early - intermediate } \\
\text { cycle) }\end{array}$ \\
\hline
\end{tabular}

(1)Number of observations. ${ }^{(2)}$ Early cycle (106 to 120 days) for cultivars Guri INTA CL and Puitá INTA-CL; and intermediate cycle (121 to 135 days) for IRGA 424 RI. 


$$
\begin{aligned}
& \text { RMSE }=\left[\frac{\sum\left(\mathrm{S}_{\mathrm{i}}-\mathrm{O}_{\mathrm{i}}\right)^{2}}{\mathrm{n}}\right]^{0.5} ; \\
& \mathrm{NRMSE}=100 \times \mathrm{RMSE} / \overline{\mathrm{O}} ; \\
& \mathrm{BIAS}=\frac{\sum \mathrm{S}_{\mathrm{i}}-\sum \mathrm{O}_{\mathrm{i}}}{\sum \mathrm{O}_{\mathrm{i}}} ; \text { and } \\
& \mathrm{d}_{\mathrm{w}}=1-\frac{\sum\left(\mathrm{S}_{\mathrm{i}}-\mathrm{O}_{\mathrm{i}}\right)^{2}}{\left[\left(\left|\mathrm{~S}_{\mathrm{i}}-\overline{\mathrm{O}}\right|\right)+\left(\left|\mathrm{O}_{\mathrm{i}}-\overline{\mathrm{O}}\right|\right)\right]^{2}} .
\end{aligned}
$$

For precision metrics, the adjusted coefficient of determination $\left(\mathrm{R}_{\mathrm{a}}^{2}\right)$ (Srivastava et al., 1995) was obtained by:

$$
\mathrm{R}_{\mathrm{a}}{ }_{\mathrm{a}}=\frac{\sum_{\mathrm{i}-1}^{\mathrm{N}}\left(\mathrm{S}_{\mathrm{i}}-\overline{\mathrm{O}}\right)^{2}}{\sum_{\mathrm{i}-1}^{\mathrm{N}}\left(\mathrm{O}_{\mathrm{i}}-\overline{\mathrm{O}}\right)^{2}} .
$$

Finally, for trend metrics, the systematic error (SE) was determined by (Streck et al., 2008):

$$
\mathrm{SE}=\sqrt{\frac{\sum_{i-1}^{N}(O i-\bar{O})^{2}}{n}}
$$

In all equations, $\mathrm{S}_{\mathrm{i}}$ represents the simulated values; $\mathrm{S}$ is the mean of the simulated values; Oi are the observed values; $\overline{\mathrm{O}}$ is the mean of the observed values; and $\mathrm{n}$ is the number of observations.

\section{Results and Discussion}

The maximum appearance rates of the first and second leaves were similar for the Guri INTA CL, Puitá INTA-CL, and IRGA 424 RI cultivars (Table 2), indicating that leaf appearance did not differ among these three genotypes. For total thermal time necessary to complete the sowing-emergence phase, the duration of the emergence-panicle differentiation and panicle differentiation-anthesis phases was shorter for the cultivars from the early maturity group (Table 2), as also verified for rice hybrids by Ribas et al. (2017). In addition, the values obtained for radiation use efficiency and the leaf area index for the Puitá INTACL cultivar and for radiation use efficiency for Guri INTA CL were higher than those for IRGA 424 RI, indicating greater efficiency in converting light energy (solar radiation) into chemical energy (photosynthesis). However, due to their lower spike formation factor and maximum grain weight, the Puitá INTA-CL and Guri INTA CL cultivars showed lower grain yields of 10.2 and $11.5 \mathrm{Mg} \mathrm{ha}^{-1}$, respectively, compared with that of 13.2 $\mathrm{Mg} \mathrm{ha}^{-1}$ for IRGA 424 RI (Table 2).

Despite a general slight underestimation, the SimulArroz model accurately simulated the cumulative number of leaves on the main stem (Figure $1 \mathrm{~A}$ ), with a RMSE equal to 1 leaf, which is close to the values of 0.6 to 1.48 leaf found for rice by Streck et al. (2008) using the Streck, Wang \& Engel, and phyllochron models. In all cases, the other used statistics indicated a good model performance for this variable. A slight overestimate of the R1, R4, and R9 stages was observed, as shown by the RMSE ranging from 3 to 8 days and by the NRMSE ranging from 6 to $26 \%$ (Figure $1 \mathrm{~B}$ ). These values are similar to those of 3 to 7

Table 2. Parameters of the leaf production and phenology submodels in the SimulArroz model calibrated for three floodirrigated rice (Oryza sativa) cultivars.

\begin{tabular}{lcccc}
\hline \multirow{2}{*}{ Parameter $^{(1)}$} & Unit & \multicolumn{2}{c}{ Cultivar } \\
\cline { 2 - 5 } LAR $_{\max 1,2}$ & & IRGA 424 RI & Guri INTA CL & Puitá INTA-CL \\
TTEM & Leaves per day & 0.272 & 0.276 & 0.276 \\
TTVG & ${ }^{\circ} \mathrm{C}$ day & 80.0 & 80.0 & 80.0 \\
TTRP & ${ }^{\circ} \mathrm{C}$ day & 659.2 & 581.6 & 591.4 \\
TTEG & ${ }^{\circ} \mathrm{C}$ day & 168.4 & 134.6 & 156.85 \\
RUE & ${ }^{\circ} \mathrm{C}$ day & 108.7 & 95.9 & 89.81 \\
LAI & $\mathrm{g} \mathrm{MJ}^{-1}$ & 2.87 & 2.65 & 2.77 \\
SOCF & - & 8.3 & 8.3 & 6.46 \\
Pmax & Spikelets per gram MS & 70.0 & 90.0 & 90.0 \\
\hline
\end{tabular}

${ }^{(1)} \mathrm{LAR}_{\max 1,2}$, maximum appearance rate of the first and second leaves; TTEM, total thermal time to complete the sowing-emergence phase; TTVG, total thermal time to complete the emergence-panicle differentiation phase; TTRP, total thermal time to complete the panicle differentiation-anthesis phase; TTEG, total thermal time to complete the anthesis-maturation phase; RUE, radiation use efficiency; LAI, leaf area index; SOCF, spike formation factor; and Pmax, maximum grain weight. 
days obtained for RMSE using the ORYZA2000 model for rice (Van Oort et al., 2011). In Italy, Mongiano et al. (2019) reported values of 5.5 in R1 and 7.1 in R9 for RMSE, and of $6.2 \%$ in R1 and $22 \%$ in R9 for NRMSE using the WOFOST_GT model, also for rice. Overall, the SimulArroz model showed a good performance in simulating rice phenology for the three studied genotypes (Figure $1 \mathrm{~B}$ ).

The IRGA 424 RI, Guri INTA CL, and Puitá INTA-CL cultivars allocated more photoassimilates into leaves, translocating over $50 \%$ until the 0.43 development stage (Table 3), compared with rice hybrids, which allocated $40 \%$ into leaves (Ribas et al., 2017). According to these authors, rice hybrids allocate more photoassimilates into stems to sustain a larger panicle. In general, SimulArroz had a reasonable accuracy in simulating aboveground biomass accumulation (Figure $2 \mathrm{~A}$ to $\mathrm{D}$ ). The RMSE to simulate aboveground dry matter, leaves, stems, and panicles for the IRGA 424 RI cultivar ranged from 1.0 to $3.0 \mathrm{Mg} \mathrm{ha}^{-1}$. The values of the bias index showed an overestimation of the model for the Guri INTA CL and Puitá INTA-CL cultivars regarding dry matter partitioning, with the exception of total dry matter
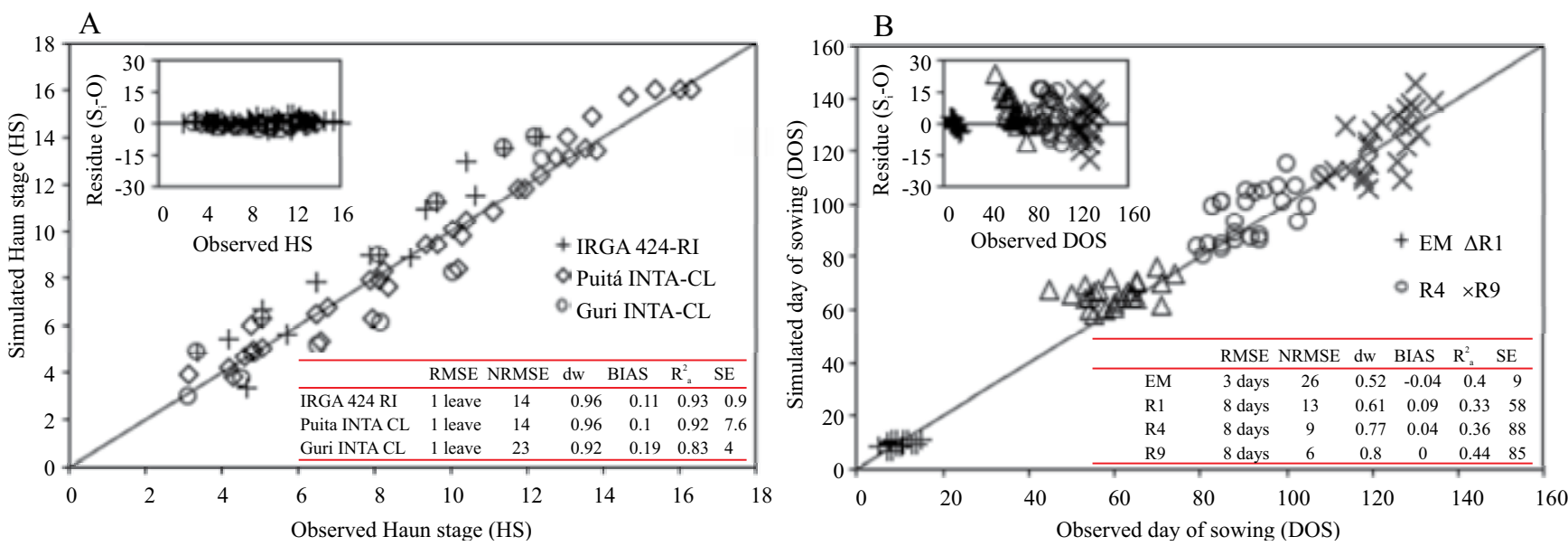

Figure 1. Evaluation of the SimulArroz model in simulating the Haun stage (A) and days of sowing according to the Counce scale (B). RMSE (leaves or days), root-mean-square error; NRMSE (\%), normalized-root-mean-square error; dw, agreement index; BIAS, bias index; $\mathrm{R}_{\mathrm{a}}{ }_{\mathrm{a}}(\%)$, adjusted coefficient of determination; SE (\%), systematic error; EM, sowing-emergence phase; R1, panicle differentiation; R4, anthesis; and R9, physiological maturity. The model was run in the potential yield mode for three flood-irrigated rice (Oryza sativa) cultivars in two crop seasons in the state of Rio Grande do Sul, Brazil (Table 1).

Table 3. Parameters partitioning dry matter, development stage (DVS), leaves (L), stems (S), and panicles (P) of the SimulArroz model calibrated for three flood-irrigated rice (Oryza sativa) cultivars, compared with rice hybrids that were already running in the model in the potential yield mode.

\begin{tabular}{|c|c|c|c|c|c|c|c|c|c|c|c|c|c|}
\hline \multirow[t]{2}{*}{$\mathrm{DVS}^{(1)}$} & \multirow{2}{*}{$\begin{array}{l}\text { Aboveground } \\
\text { dry matter }\end{array}$} & \multicolumn{3}{|c|}{ IRGA 424 RI } & \multicolumn{3}{|c|}{ Guri INTA CL } & \multicolumn{3}{|c|}{ Puitá INTA-CL } & \multicolumn{3}{|c|}{ Hybrid } \\
\hline & & $\mathrm{L}$ & $\mathrm{S}$ & $\mathrm{P}$ & $\mathrm{L}$ & $\mathrm{S}$ & $\mathrm{P}$ & $\mathrm{L}$ & $S$ & $P$ & $\mathrm{~L}$ & $\mathrm{~S}$ & $\mathrm{P}$ \\
\hline 0 & 0.5 & 0.73 & 0.27 & 0.0 & 0.7 & 0.30 & 0.0 & 0.75 & 0.30 & 0.0 & 0.4 & 0.6 & 0.0 \\
\hline 0.43 & 0.75 & 0.5 & 0.5 & 0.0 & 0.6 & 0.4 & 0.0 & 0.48 & 0.52 & 0.0 & 0.4 & 0.6 & 0.0 \\
\hline 0.75 & 0.75 & 0.3 & 0.7 & 0.0 & 0.2 & 0.8 & 0.0 & 0.20 & 0.80 & 0.0 & 0.3 & 0.7 & 0.0 \\
\hline 1.0 & 1.0 & 0.0 & 0.9 & 0.1 & 0.0 & 0.8 & 0.2 & 0.0 & 0.80 & 0.2 & 0.1 & 0.3 & 0.6 \\
\hline 1.2 & 1.0 & 0.0 & 0.0 & 1.0 & 0.0 & 0.0 & 1.0 & 0.0 & 0.0 & 1.0 & 0.0 & 0.0 & 1.0 \\
\hline 1.6 & 1.0 & 0.0 & 0.0 & 1.0 & 0.0 & 0.0 & 1.0 & 0.0 & 0.0 & 1.0 & 0.0 & 0.0 & 1.0 \\
\hline 2.0 & 1.0 & 0.0 & 0.0 & 1.0 & 0.0 & 0.0 & 1.0 & 0.0 & 0.0 & 1.0 & 0.0 & 0.0 & 1.0 \\
\hline
\end{tabular}

(1) 0 , emergency; 1.0, anthesis or flowering; and 2.0, physiological maturity. 
for Guri INTA CL, as well as an underestimation for IRGA 424 RI, except for leaf dry matter. Moreover, the $\mathrm{dw}$ index indicated a good performance of the model, with values above 0.80 (Figure 2). As a result, SE and Ra2 ranged from 0.6 to $9.3 \%$ and from 0.52 to 0.97, respectively, for dry matter. Tang et al. (2009),
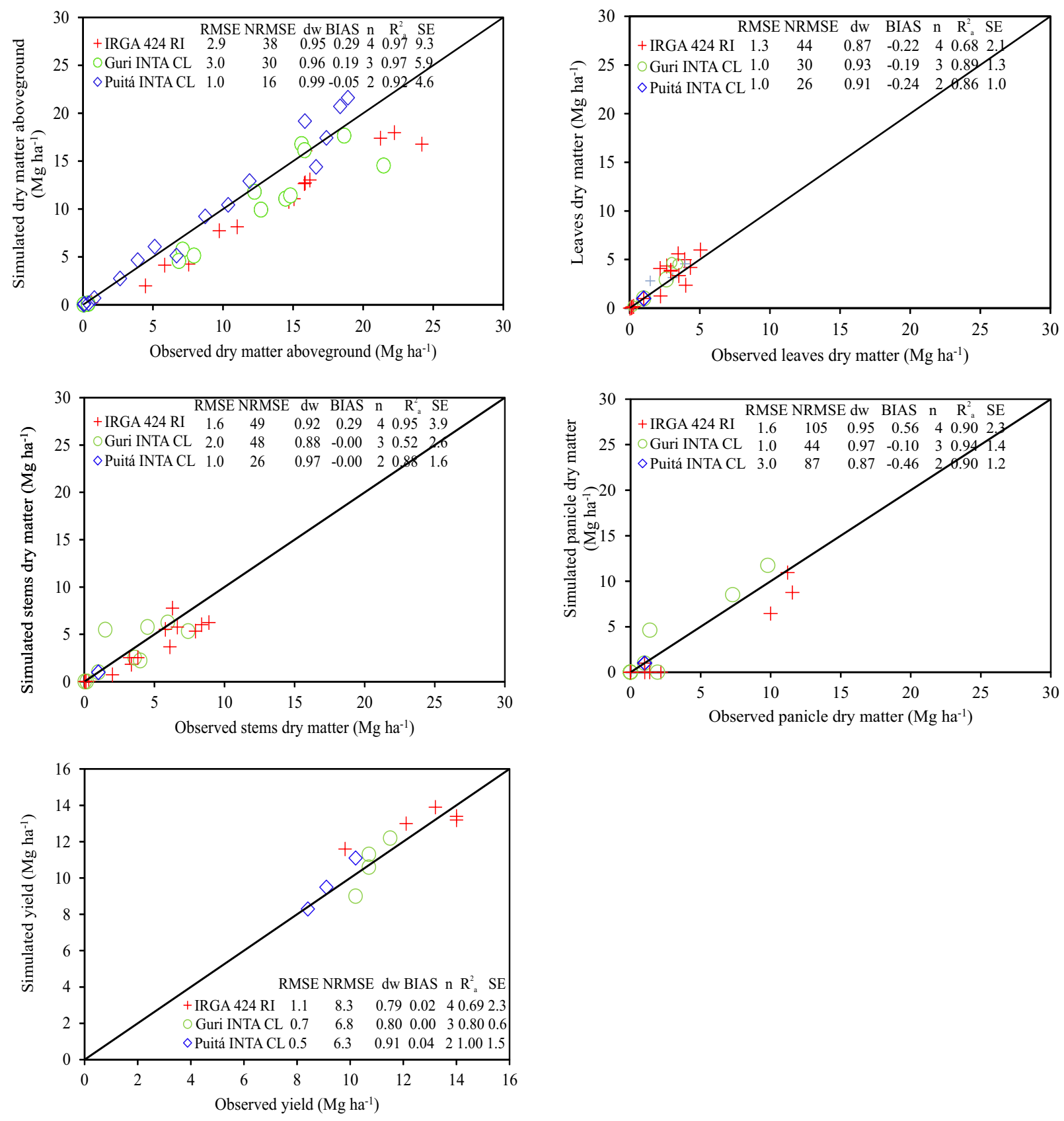

Figure 2. Evaluation of the SimulArroz model regarding the total aboveground dry matter (DM) (A) and the dry matter of leaves (B), stems (C), and panicles (D), as well as grain yield at 13\% moisture (E). The model was run in the potential yield mode for three flood-irrigated rice (Oryza sativa) cultivars, in two crop seasons and two sites in the state of Rio Grande do Sul, Brazil (Table 1). RMSE (Mg ha-1), root-mean-square error; NMRSE (\%), normalized-root-mean-square error; dw, agreement index; BIAS, bias index; n, number of observations; $\mathrm{R}^{2}{ }_{\mathrm{a}}(\%)$, adjusted coefficient of determination; and SE (\%), systematic error. 
when describing aboveground dry matter and grain yield using the RiceGrow and ORYZA2000 models, found RMSE values from 0.2 to $0.8 \mathrm{Mg}$ ha-1 (Table 4). However, Confalonieri et al. (2016), studying rice, reported that the WARM model showed high RMSE values from 0.97 to $3.78 \mathrm{Mg} \mathrm{ha}^{-1}$ and NRMSE values from 8 to $36 \%$, respectively, for aboveground and panicle dry matter. For dry matter and grain yield, the RMSE and NRMSE of the SimulArroz model varied from 0.6 to $1.0 \mathrm{Mg} \mathrm{ha}^{-1}$ and from 6.3 to $8.3 \%$, respectively (Figure 2 E). Tang et al. (2009) and Artacho et al. (2011) achieved RMSE values ranging from 0.6 to $1.6 \mathrm{Mg} \mathrm{ha}^{-1}$ and a NRMSE of $19 \%$, slightly higher than those obtained by the SimulArroz model for grain yield in the present study.

To validate the used model for simulated grain yield, a comparison was made with the yield dataset

Table 4. Statistical analyses of the data described in the literature and estimated by the SimulArroz model, compared using calibrated mathematical models and field experimental data.

\begin{tabular}{|c|c|c|}
\hline $\begin{array}{l}\mathrm{RMSE}^{(1)} \\
\left(\mathrm{Mg} \mathrm{ha}^{-1}\right)\end{array}$ & $\begin{array}{c}\mathrm{NRMSE}^{(2)} \\
(\%)\end{array}$ & Model, country, and reference \\
\hline \multicolumn{3}{|c|}{ Aboveground dry matter } \\
\hline 0.5 & 20 & Oyza2000, Philippines, Boling et al. (2011) \\
\hline 2.2 & 19 & Oyza2000, Chile, Artacho et al. (2011) \\
\hline 0.8 & 12 & InfoCrop, India, Aggarwal et al. (2006) \\
\hline 0.7 & - & RiceGrow, China, Tang et al. (2009) \\
\hline 0.8 & - & Oryza2000, China, Tang et al. (2009) \\
\hline 2.5 & 27 & SimulArroz, Brazil, present study \\
\hline \multicolumn{3}{|c|}{ Leaf dry matter } \\
\hline 0.9 & 47 & Oyza2000, Chile, Artacho et al. (2011) \\
\hline 0.2 & - & RiceGrow, China, Tang et al. (2009) \\
\hline 1.2 & 35 & SimulArroz, Brazil, present study \\
\hline \multicolumn{3}{|c|}{ Stem dry matter } \\
\hline 2.2 & 37 & Oyza2000, Chile, Artacho et al. (2011) \\
\hline 1.5 & 68 & SimulArroz, Brazil, present study \\
\hline \multicolumn{3}{|c|}{ Panicle dry matter } \\
\hline 1.7 & 72 & Oyza2000, Chile, Artacho et al. (2011) \\
\hline 2.5 & 75 & SimulArroz, Brazil, present study \\
\hline \multicolumn{3}{|c|}{ Grain yield } \\
\hline 0.6 & - & RiceGrow, China, Tang et al. (2009) \\
\hline 1.6 & 19 & Oyza2000, Chile, Artacho et al. (2011) \\
\hline 1.0 & 7 & SimulArroz, Brazil, present study \\
\hline
\end{tabular}

(1)RMSE, root-mean-square error. (2)NMRSE, normalized-root-meansquare error. of the experiments with different sowing dates of the IRGA 424 RI, Guri INTA CL, and Puitá INTA-CL cultivars, with RMSE and NRMSE ranging from 0.8 to $1.3 \mathrm{Mg} \mathrm{ha}^{-1}$ and from 10.5 to $11.2 \%$, respectively. In China, Boling et al. (2011) observed a RMSE of $0.6 \mathrm{Mg} \mathrm{ha}^{-1}$ and a NRMSE of $20.4 \%$ for rice, within the range of errors of the present study. Likewise, in Italy, Mongiano et al. (2019) reported RMSE and NRMSE of $0.81 \mathrm{Mg} \mathrm{ha}^{-1}$ and $13.2 \%$, respectively, using the WOFOST_GT model. SimulArroz simulated yields from 4.1 to $15.0 \mathrm{Mg} \mathrm{ha}^{-1}$, indirectly proving the robustness of the model approach (Figure 3). The relationship between the experimental data and the data generated by the model confirmed the goodness of fit of the model for yield, with $\mathrm{R}_{\mathrm{a}}{ }^{2}$ from 0.59 to 0.78 and $\mathrm{SE}$ of $8.9 \%$; these results are in agreement with the literature (Balbinoti et al., 2018a; Dauer et al., 2018; Mongiano et al., 2019).

Rice models have, therefore, been used by researchers worldwide to estimate yield impact due to stacking resistance in Clearfield rice (Dauer et al., 2018), rice hydration at different thermal conditions (Balbinoti et al., 2018a), and rice yield potential and yield gap (Deng et al., 2019; Liu et al., 2019), as well as to model rice structure and protein-ligand interactions (Baicharoen et al., 2018), which could enhance rice

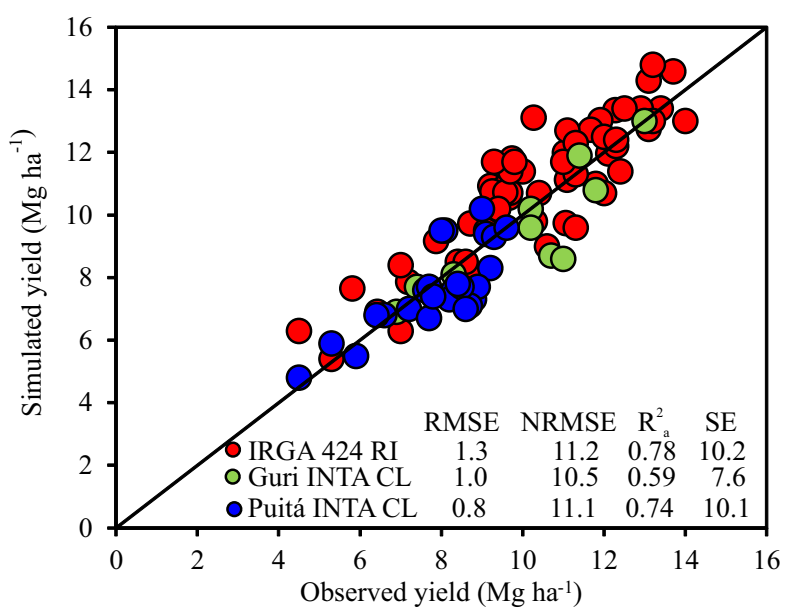

Figure 3. Evaluation of the SimulArroz model regarding the observed grain yield, at 13\% moisture, of three floodirrigated rice (Oryza sativa) cultivars in experiments with different sowing dates. The model was run in the high technology level mode in five sites and four crop seasons (Table 1). Statistical analyses are shown. 
quality, improve market price, and increase yield without requiring a greater area. Furthermore, models with the same fits are mathematically identical and can be used to model plant behavior (Balbinoti et al., 2018b; Dauer et al., 2018; Baicharoen et al., 2018). In the present study, the analysis of the statistical parameters allowed concluding that the SimulArroz model may describe, with the same degree of quality, the growth and development of flood-irrigated rice.

The robustness and accuracy of SimulArroz, combined with its low requirements in terms of inputs for reproducing the biophysical processes that strongly influence the year-to-year yield variation, make the model suitable for the grain yields of the most important cultivars of flood-irrigated rice in the state of Rio Grande do Sul. The model can be applied with confidence to explore potential yields in this state and, in the present study, confirmed the existence of a yield gap between potential and actual yields. The average simulated yield potential of $13.5 \mathrm{Mg} \mathrm{ha}^{-1}$ exceeded the actual yield of $7.5 \mathrm{Mg} \mathrm{ha}^{-1}$ of the IRGA $424 \mathrm{RI}$, Guri INTA CL, and Puitá INTA-CL cultivars in the same crop season (Irga, 2018).

\section{Conclusions}

1. The SimulArroz model allows predicting variations in the growth, development, and grain yield, within years and locations, of the IRGA 424 RI, Puitá INTA-CL, and Guri INTA flood-irrigated rice (Oryza sativa) cultivars, with a normalized-root-mean-square error from 6 to $105 \%$.

2. The evaluation of the means of the parameters root-mean-square error (7 days for phenology and $1.4 \mathrm{Mg} \mathrm{ha}^{-1}$ for dry matter and grain yield), adjusted coefficient of determination (0.77), and systematic error $(13 \%)$ shows that the SimulArroz model presents a good fit to the experimental data of 109 field experiments in the major rice-producing area of the state of Rio Grande do Sul, Brazil, with a mean relative error of $28 \%$, indicating that, due to its predictive ability, the model can be used for potential yield and yield gap studies.

\section{References}

ACOMPANHAMENTO DA SAFRA BRASILEIRA [DE] GRÃOS: safra 2019/20: primeiro levantamento, v.7, n.1, out. 2019.
Available at: <https://www.conab.gov.br/info-agro/safras/graos/ boletim-da-safra-de-graos $>$. Accessed on: Oct 12019.

AGGARWAL, P.K.; KALRA, N.; CHANDER, S.; PATHAK, H. InfoCrop: a dynamic simulation model for the assessment of crop yields, losses due to pests, and environmental impact of agro-ecosystems in tropical environments. I. Model description. Agricultural Systems, v.89, p.1-25, 2006. DOI: https://doi.org/10.1016/j.agsy.2005.08.001.

ARTACHO, P.; MEZA, F.; ALCALDE, J.A. Evaluation of the Oryza2000 rice growth model under nitrogen-limited conditions in an irrigated Mediterranean environment. Chilean Journal of Agricultural Research, v.71, p.23-33, 2011. DOI: https://doi.org/10.4067/S0718-58392011000100003.

BAICHAROEN, A.; VIJAYAN, R.; PONGPRAYOON, P. Structural insights into betaine aldehyde dehydrogenase (BADH2) from Oryza sativa explored by modeling and simulations. Scientific Reports, v.8, art.12892, 2018. DOI: https://doi.org/10.1038/s41598-018-31204-z.

BALBINOTI, T.C.V.; JORGE, L.M. de M.; JORGE, R.M.M. Mathematical modeling of paddy (Oryza sativa) hydration in different thermal conditions assisted by Raman spectroscopy. Journal of Cereal Science, v.79, p.390-398, 2018a. DOI: https://doi.org/10.1016/j.jcs.2017.11.019.

BALBINOTI, T.C.V.; JORGE, L.M. de M.; JORGE, R.M.M. Modeling the hydration step of the rice (Oryza sativa) parboiling process. Journal of Food Engineering, v.216, p.81-89, 2018b. DOI: https://doi.org/10.1016/j.jfoodeng.2017.07.020.

BOLING, A.A.; BOUMAN, B.A.M.; TUONG, T.P.; KONBOON, Y.; HARNPICHITVITAYA, D. Yield gap analysis and the effect of nitrogen and water on photoperiod-sensitive Jasmine rice in north-east Thailand. Wageningen Journal of Life Sciences, v.58, p.11-19, 2011. DOI: https://doi.org/10.1016/j.njas.2010.05.001.

BOOTE, K.J.; KROPFF, M.J.; BINDRABAN, P.S. Physiology and modelling of traits in crop plants: implications for genetic improvement. Agricultural System, v.70, p.395-420, 2001. DOI: https://doi.org/10.1016/s0308-521x(01)00053-1.

BRASIL. Ministério da Agricultura, Pecuária e Abastecimento. Portaria $n^{\circ} 41$, de 27 de junho de 2019. [Aprova o Zoneamento Agrícola de Risco Climático para a cultura de arroz irrigado no Estado do Rio Grande do Sul, ano-safra 2019/2020, conforme anexo]. Diário Oficial da União, 5 jul. 2019. Seção 1, p.16-39.

CASSMAN, K.G.; DOBERMANN, A.; WALTERS, D.T.; YANG, H. Meeting cereal demand while protecting natural resources and improving environmental quality. Annual Review of Environment and Resources, v.28, p.315-358, 2003. DOI: https://doi.org/10.1146/annurev.energy.28.040202.122858.

CASTRO, J.R. de; CUADRA, S.V.; PINTO, L.B.; SOUZA, J.M.H. de; SANTOS, M.P. dos; HEINEMANN, A.B. Parametrization of models and use of estimated global solar radiation data in the irrigated rice yield simulation. Revista Brasileira de Meteorologia, v.33, p.238-246, 2018. DOI: https://doi.org/10.1590/0102-7786332003.

CONFALONIERI, R.; BREGAGLIO, S.; ACUTIS, M. Quantifying uncertainty in crop model predictions due to the uncertainty in the observations used for calibration. Ecological 
Modelling, v.328, p.72-77, 2016. DOI: https://doi.org/10.1016/j. ecolmodel.2016.02.013.

COUNCE, P.A.; KEISLING, T.C.; MITCHELL, A.J. A uniform, objective, and adaptive system for expressing rice development. Crop Science, v.40, p.436-443, 2000. DOI: https://doi.org/10.2135/ cropsci2000.402436x.

DAUER, J.; HULTING, A.; CARLSON, D.; MANKIN, L.; HARDEN, J.; MALLORY-SMITH, C. Gene flow from single and stacked herbicide-resistant rice (Oryza sativa): modeling occurrence of multiple herbicide-resistant weedy rice. Pest Management Science, v.74, p.348-355, 2018. DOI: https://doi. org $/ 10.1002 /$ ps. 4711 .

DENG, N.; GRASSINI, P.; YANG, H.; HUANG, J.; CASSMAN, K.G.; PENG, S. Closing yield gaps for rice self-sufficiency in China. Nature Communications, v.10, art.1725, 2019. DOI: https://doi.org/10.1038/s41467-019-09447-9.

EVANS, L.T. Crop evolution, adaptation and yield. Cambridge: Cambridge University Press, 1993.

FAO. Food and Agriculture Organization of the United States. Faostat. Available at: <www.fao.org/faostat/en/\#data/QC $>$. Accessed on: May 12018.

GABRIEL, L.F.; STRECK, N.A.; ROBERTI, D.R.; CHIELLE, Z.G.; UHLMANN, L.O.; SILVA, M.R. da.; SILVA, S.D. da. Simulating cassava growth and yield under potential conditions in Southern Brazil. Agronomy Journal, v.106, p.1119-1137, 2014. DOI: https://doi.org/10.2134/agronj2013.0187.

GRASSINI，P.; TORRION, J.A.; YANG, H.S.; REES, J.; ANDERSEN, D.; CASSMAN, K.G.; SPECHT, J.E. Soybean yield gaps and water productivity in the western U.S. Corn Belt. Field Crops Research, v.179, p.150-163, 2015. DOI: https://doi.org/10.1016/j.fcr.2015.04.015.

HAUN, J.R. Visual quantification of wheat development. Agronomy Journal, v.65, p.116-119, 1973. DOI: https://doi.org/10.2134/agronj1973.00021962006500010035x.

HEINEMANN, A.B.; HOOGENBOOM, G.; FARIA, R.T. de. Determination of spatial water requirements at county and regional levels using crop models and GIS: an example for the State of Parana, Brazil. Agricultural Water Management, v.52, p.177196, 2002. DOI: https://doi.org/10.1016/S0378-3774(01)00137-8.

HOSSARD, L.; BREGAGLIO, S.; PHILIBERT, A.; RUGET, F.; RESMOND, R.; CAPPELLI, G.; DELMOTTE, S. A web application to facilitate crop model comparison in ensemble studies. Environmental Modelling \& Software, v.97, p.259-270, 2017. DOI: https://doi.org/10.1016/j.envsoft.2017.08.008.

IRGA. Instituto Rio Grandense do Arroz. [Levantamento da área semeada com arrozirrigado no Rio Grande do Sul]. Available at: $<$ https://irga-admin.rs.gov.br/upload/arquivos/201906/07134923colheita-18-19.pdf >. Accessed on: Feb. 202018.

ITTERSUM, M.K. van; CASSMAN, K.G.; GRASSINI, P.; WOLF, J.; TITTONELL, P.; HOCHMAND, Z. Yield gap analysis with local to global relevance - a review. Field Crops Research, v.143, p.4-17, 2013. DOI: https://doi.org/10.1016/j.fcr.2012.09.009.

ITTERSUM, M.K. van; RABBINGE, R. Concepts in production ecology for analysis and quantification of agricultural input- output combinations. Field Crops Research, v.52, p.197-208, 1997. DOI: https://doi.org/10.1016/s0378-4290(97)00037-3.

JANSSEN, P.H.M.; HEUBERGER, P.S.C. Calibration of processoriented models. Ecological Modelling, v.83, p.55-56, 1995. DOI: https://doi.org/10.1016/0304-3800(95)00084-9.

LIU, Y.; LI, C.; FANG, B.; FANG, Y.; CHEN, K.; ZHANG, Y.; ZHANG, H. Potential for high yield with increased seedling density and decreased $\mathrm{N}$ fertilizer application under seedlingthrowing rice cultivation. Scientific Reports, v.9, art.731. 2019. DOI: https://doi.org/10.1038/s41598-018-36978-w.

LOBELL, D.B.; CASSMAN, K.G.; FIELD, C.B. Crop yield gaps: their importance, magnitudes, and causes. Annual Review of Environment and Resources, v.34, p.179-204, 2009. DOI: https://doi.org/10.1146/annurev.environ.041008.093740.

MENEZES, V.G.; ANGHINONI, I.; SILVA, P.R.F. da; MACEDO, V.R.M.; PETRY, C.; GROHS, D.S.; FREITAS, T.F.S. de; VALENTE, L.A. de L. Projeto 10: management strategies to increase productivity and sustainability of irrigated rice fields growth in the state of Rio Grande do Sul, Brazil: developments and new challenges. Porto Alegre: IRGA, 2013. Available at: $<\mathrm{http}: / /$ oryzasoy.com/publicacoes/projeto-10-management-strategies-toincrease-productivity-and-sustainability-of-irrigated-rice-fieldsgrowth-in-the-state-of-rio-grande-do-sul-brazil-developmentsand-new-challenges/>. Accessed on: Dec. 182019.

MONGIANO, G.; TITONE, P.; TAMBORINI, L.; PILU, R.; BREGAGLIO, S. Advancing crop modelling capabilities through cultivar-specific parameters sets for the Italian rice germplasm. Field Crops Research, v.240, p.44-54, 2019. DOI: https://doi.org/10.1016/j.fcr.2019.05.012.

RAMIREZ-VILLEGAS, J.; HEINEMANN, A.B.; CASTRO, A.P. de; BRESEGHELLO, F.; NAVARRO-RACINES, C.; LI, T.; REBOLLEDO, M.C.; CHALLINOR, A.J. Breeding implications of drought stress under future climate for upland rice in Brazil. Global Change Biology, v.24, p.2035-2050, 2018. DOI: https://doi.org/10.1111/gcb.14071.

RATTALINO EDREIRA, J.I.; MOURTZINIS, S.; CONLEY, S.P.; ROTH, A.C.; CIAMPITTI, I.A.; LICHT, M.A.; KANDEL, H.; KYVERYGA, P.M.; LINDSEY, L.E.; MUELLER, D.S.; NAEVE, S.L.; NAFZIGER, E.; SPECHT, J.E.; STANLEY, J.; STATON, M.J.; GRASSINI, P. Assessing causes of yield gaps in agricultural areas with diversity in climate and soils. Agricultural and Forest Meteorology, v.247, p.170-180, 2017. DOI: https://doi.org/10.1016/j.agrformet.2017.07.010.

RIBAS, G.G.; STRECK, N.A.; DUARTE JUNIOR, A.J.; NASCIMENTO, M.F. do; ZANON, A.J.; SILVA, M.R. da. Number of leaves and phenology of rice hybrids simulated by the SimulArroz model. Revista Brasileira de Engenharia Agrícola e Ambiental, v.21, p.221-226, 2017. DOI: https://doi.org/10.1590/1807-1929/agriambi.v21n4p221-226.

RICHTER, G.L.; STRECK, N.A.; ZANON, A.J.; ULGUIM, A. da R.; KRUSE, N.D.; SANTOS, G.A. de A. dos; CERA, J.C.; RIBAS, G.G.; DUARTE JUNIOR, A.J.; PILECCO, I.B. Introducing rice yield loss caused by weed competition into the SimulArroz model. Pesquisa Agropecuária Brasileira, v.54, e01418, 2019. DOI: https://doi.org/10.1590/ S1678-3921.pab2019.v54.01418. 
ROSA, H.T.; WALTER, L.C.; STRECK, N.A.; DE CARLI, C.; RIBAS, G.G.; MARCHESAN, E. Simulação do crescimento e produtividade de arroz no Rio Grande do Sul pelo modelo SimulArroz. Revista Brasileira de Engenharia Agrícola e Ambiental, v.19, p.1159-1165, 2015. DOI: https://doi.org/10.1590/1807-1929/agriambi.v19n12p1159-1165.

SRIVASTAVA, A.K.; SRIVASTAVA, V K.; ULLAH, A. The coefficient of determination and its adjusted version in linear regression models. Econometric Reviews, v.14, p.229-240, 1995. DOI: https://doi.org/10.1080/02664760802553000.

STRECK, N.A.; BOSCO, L.C.; LAGO, I. Simulating leaf appearance in rice. Agronomy Journal, v.100, p.490-501, 2008. DOI: https://doi.org/10.2134/agronj2007.0156.

TANG, L.; ZHU, Y.; HANNAWAY, D.; MENG, Y.; LIU, L.; CHEN, L.; CAO, W. RiceGrow: a rice growth and productivity model. Wageningen Journal of Life Sciences, v.57, p.83-92, 2009. DOI: https://doi.org/10.1016/j.njas.2009.12.003.

USDA. United States Department of Agriculture. Production, Supply and Distribution. Available at: <www.usda.gov/wps/ portal/usda/usdahome?navid=DATA_STATISTICS $>$. Accessed on: Feb. 202018.

VAN OORT, P.A.J.; ZHANG, T.; DE VRIES, M.E.; HEINEMANN, A.B.; MEINKE, H. Correlation between temperature and phenology prediction error in rice (Oryza sativa L.). Agricultural and Forest Meteorology, v.151, p.1545-1555, 2011. DOI: https://doi.org/10.1016/j.agrformet.2011.06.012.

WALTER, L.C.; STRECK, N.A.; ROSA, H.T. Mecanismos de aclimatação das plantas à elevada concentração de $\mathrm{CO}_{2}$. Ciência Rural, v.45, p.1564-1571, 2015. DOI: https://doi.org/10.1590/01038478 cr20140527. 